\title{
Artemisiaderived Actinobacteria Producing Inhibitors of Spodoptera Littoralis via Molecular Modeling Studies
}

Mohamed K. Diab

Agriculture Research Center

Hala M. Mead

Agriculture Research Center

Mohamad A. Khedr

Agriculture Research Center

Mohamed S. Nafie

Suez Canal University Faculty of Science

Abdelghafar M. Abu-Elsaoud

Suez Canal University Faculty of Science

Sahar Ahmed El-Shatoury ( $\nabla$ sahar_hassan@science.suez.edu.eg )

Suez Canal University https://orcid.org/0000-0002-6093-5145

\section{Research Article}

Keywords: Kitasatospora sp., lepidopterous larvae, endophytes, cyromazine, 4-nitrophenol, medicinal plants

Posted Date: November 8th, 2021

DOl: https://doi.org/10.21203/rs.3.rs-878185/v1

License: (9) This work is licensed under a Creative Commons Attribution 4.0 International License. Read Full License 


\section{Abstract}

Insecticide resistance in agricultural pests has prompted the need to discover novel compounds with new modes of action. We investigated the potency of secondary metabolites from seventy endophytic actinobacteria against laboratory and field strains of Spodoptera littoralis ( $4^{\text {th }}$ instar), comparable to spinetoram (Radiant ${ }^{\circledR} 12 \%$ SC). Endophytes from Artemisia herba-alba (syn. Seriphidium herba-alba) and Artemisia judaica were highly effective. Chemical profiling of the most potent metabolite was investigated using LC-QTOF-MS-MS technique, and the activity was validated through molecular docking studies. Metabolic extracts from seven actinobacteria (belonging to Streptomyces, Nocardioides, Kitasatospora and Pseudonocardia) have shown lethality to the $4^{\text {th }}$ instar larvae. The metabolite ES2, from Kitasatospora sp., caused significant histopathological and inhibitory effects on $4^{\text {th }}$ instar larvae. Additionally, ES2 caused lesions in the body wall cuticle, indicating a different mode of action than that of spinetoram. Chemical profiling of ES2 have shown presence of cyromazine (molt inhibitor), 4nitrophenol and diazinon as key constituents. In conclusion, these findings suggest that, secondary metabolites from endophytic actinobacteria inhabiting wild medicinal plants are sustainable source for promising natural biocontrol agents. This is the first illustration of insecticidal activity of the Artemisia spp. microbiome, and the first report on a natural cyromazine synthesized by actinobacteria.

\section{Key Points}

- Endophytic Kitasatospora ES2 from Artemisia plant produce metabolites that control the 4th instar larvae of cotton leafworm, displaying toxicity, morphological defects and histopathological deformities.

- LC-Q-TOF-MS analysis shows cyromazine (a molt inhibitor), 4-nitrophenol, and diazinon insecticidal compounds as major constituents in ES2.

- Molecular docking confirms the experimental results of ES2 insecticide activity through acetylcholinesterase, lactate dehydrogenase, and protease inhibition.

\section{Introduction}

The cotton leafworm, Spodoptera littoralis (Boisduval 1833) (Lepidoptera: Noctuidae) is commonly distributed worldwide. This swarming polyphagous foliage feeding insect is one of the most destructive agricultural pests within the subtropical and tropical range (Pasiecznik et al. 2005). It causes considerable damage to plants belonging to 44 different families during the year, including cotton, ornamentals, vegetables, and many other economically important crops. Currently, new technologies based on microbe- and plant-derived insecticides have become essential because $S$. littoralis has acquired resistance to the traditionally used pesticides (Hazaa et al. 2020).

A promising strategy to find novel bioactive products is to investigate microbes from non-conventional habitats, such as the endophytes from medicinal plants. The endophyte utilizes unique nutrients that are 
peculiar of the medicinal plant to produces bioactive metabolites with distinct and novel structures (Tanvir et al. 2019). Endophytic actinobacteria are of great importance as a source of bioactive metabolites, including those for agricultural applications. Streptomyces albus, is an example of endophytes from the drunken horse grass, Achnatherum inebrians which exhibited $>90 \%$ mortality in the cotton aphid, Aphis gossypii Glover (Shi et al. 2013). The endophytic Streptomyces sp. from Stemona sessilifolia (a traditional Chinese medicinal plant) can produce 10 new endostemonines compounds with strong lethal activity against Aphis gossypii (Zhao et al. 2020). Worth to mention, the future of endophyte-derived pesticides is not only in exploring novel products for plant protection, but also in developing self-protected plants that are augmented with the potent endophytes in its microbiome. The use of plant microbiome augmentation may allow agriculturists to more sustainably produce crops at a reduced cost (White et al. 2019).

However, only few microbial metabolites have reached the market for pest control (Kvakkestad et al. 2020). Those include, avermectins which is produced by a soil Streptomyces sp.; it acts on gammaaminobutyric acid, GABA, receptors, leading to inhibition of neurotransmission due to an increased flow of chloride ions into the cell. Also, spinosads (a spinosyns mixture, produced by the soil actinobacterium Saccharopolyspora spinosa) which act on nicotinic acetylcholine receptors, causing death due to disruption of the nervous system (Kim et al. 2010). In addition, 30 butenyl-spinosyns of higher potency are produced by Saccharopolyspora pogona (Rang et al. 2020). However, S. littoralis develops resistance due to the widespread and prolonged use of pesticides, pressing a continuous need for alternative fermentation products to control the pest.

This study aimed to investigate the insecticidal potential of the secondary metabolites produced by endophytic actinobacteria isolated from six medicinal plant species in the World Heritage Site of Saint Catherine (WHS No. 954), South Sinai, Egypt. Up to our knowledge, no previous studies exist on insecticides derived from the endophytes of this conservative area. This site can represent a source of unique and diverse endophytes from its endemic plants. The insecticidal activities were assessed on the fourth instar larvae of $S$. littoralis field strain, compared to the laboratory strain. Out of seventy endophytic strains, we found high potency for metabolites from seven strains, which were inhabiting two species of Artemisia plant, Family Compositae, (common name: wormwood). The toxicological, histopathological, and biochemical effects of the most potent actinobacterial metabolites were evaluated, as an initial effort to introduce a natural control agent for cotton leafworm. The metabolic extract from the endophyte Kitasatospora sp. ES2 has caused substantial histopathological defects and changes in the metabolism of the larvae, compared to the commercially applied pesticide.

\section{Materials And Methods}

\section{Endophytic actinobacteria and culture conditions}

Seventy actinobacteria strains, previously isolated from six wild medicinal plant species (F. Compositae) in South Sinai, Egypt (El-Shatoury et al. 2013), were studied. The strains were provided by Actinobacteria 
Lab, Botany Department, Faculty of Science, Suez Canal University. Their selection was based on their published enzymatic activity, plant growth promotion and antimicrobial activity, as shown in Supplementary (Table S1). The generic identity of the strains and their host plants is illustrated in Table 1. The strains were provided as spore suspensions in $20 \% \mathrm{v} / \mathrm{v}$ glycerol at $-15^{\circ} \mathrm{C}$, and were refreshed on starch casein agar, as described by (Kieser et al. 2000).

Table 1 Illustration of the endophytic actinobacteria strains and their host plants.

\begin{tabular}{|c|c|c|c|c|c|c|}
\hline \multirow{2}{*}{$\begin{array}{l}\text { Genus of } \\
\text { endophyte }\end{array}$} & \multicolumn{6}{|c|}{ Host plant, "common name" and Latin name } \\
\hline & $\begin{array}{l}\text { "White } \\
\text { wormwood" } \\
\text { Artemisia } \\
\text { herba-alba } \\
\text { Asso }\end{array}$ & $\begin{array}{l}\text { "Chicory" } \\
\text { Scariola } \\
\text { orientalis } \\
\text { (Boiss.) }\end{array}$ & $\begin{array}{l}\text { "Sinai tansy" } \\
\text { Tanacetum } \\
\text { sinaicum } \\
\text { (Fresen.) }\end{array}$ & $\begin{array}{c}\text { "Judean } \\
\text { Wormwood" } \\
\text { Artemisia } \\
\text { judaica L. }\end{array}$ & $\begin{array}{l}\text { "Lavender } \\
\text { Cotton" } \\
\text { Achillea } \\
\text { fragrantissim } \\
a \text { (Forssk.) }\end{array}$ & $\begin{array}{c}\text { "Globe } \\
\text { Thistle" } \\
\text { Echinops } \\
\text { spinosus L. }\end{array}$ \\
\hline Streptomyces sp. & $\begin{array}{l}21 \text { strains, } \\
30 \%\end{array}$ & $\begin{array}{c}5 \text { strains, } \\
7.1 \%\end{array}$ & $\begin{array}{c}2 \text { strains, } \\
2.9 \%\end{array}$ & & & \\
\hline Nocardiopsis sp. & $\begin{array}{l}5 \text { strains, } \\
7.1 \%\end{array}$ & & $\begin{array}{c}1 \text { strain, } \\
1.4 \%\end{array}$ & & & \\
\hline Nocardioides sp. & $\begin{array}{l}16 \text { strains, } \\
22.9 \%^{\mathrm{a}}\end{array}$ & $\begin{array}{c}1 \text { strain, } \\
1.4 \%\end{array}$ & & $\begin{array}{c}1 \text { strain, } \\
1.4 \%\end{array}$ & $\begin{array}{c}1 \text { strain, } \\
1.4 \%\end{array}$ & \\
\hline Kitasatospora sp. & & & & $\begin{array}{c}5 \text { strains, } \\
7.1 \%{ }^{\mathrm{a}}\end{array}$ & $\begin{array}{c}2 \text { strains, } \\
2.9 \%\end{array}$ & $\begin{array}{c}2 \text { strains, } \\
2.9 \%\end{array}$ \\
\hline Pseudonocardia sp. & $\begin{array}{c}1 \text { strain, } \\
1.4 \%\end{array}$ & & & $\begin{array}{l}1 \text { strain, } \\
1.4 \%\end{array}$ & & \\
\hline Nocardia sp. & $\begin{array}{c}1 \text { strain, } \\
1.4 \%\end{array}$ & & & & & \\
\hline $\begin{array}{l}\text { Kibdellosporangium } \\
\text { sp. }\end{array}$ & & & & & $\begin{array}{c}1 \text { strain, } \\
1.4 \%\end{array}$ & \\
\hline $\begin{array}{l}\text { Promicromonospora } \\
\text { sp. }\end{array}$ & & & & $\begin{array}{c}1 \text { strain, } \\
1.4 \%\end{array}$ & & \\
\hline Unknown spp. & $\begin{array}{c}2 \text { strains, } \\
2.9 \%\end{array}$ & $\begin{array}{c}1 \text { strain, } \\
1.4 \%\end{array}$ & & & & \\
\hline
\end{tabular}

The origin of the seven endophytes that showed the highest effects on the laboratory S. littoralis strain in the initial screen are highlighted in grey

a indicates the origin of the four endophytes that showed potent effects on the field $S$. littoralis strains.

\section{S. littoralis larvae rearing}

The laboratory $S$. littoralis strain was reared under constant laboratory conditions at the Plant Protection Research Institute, Agricultural Research Center, Zagazig, Egypt. It was reared in an incubator at a temperature of $26 \pm 2^{\circ} \mathrm{C}$ and a relative humidity of $65 \pm 10 \% \mathrm{RH}$ with a $16 \mathrm{~L}$ : $8 \mathrm{D}$ photoperiod, according to (El-Defrawi et al., 1964). The details are shown in Supplementary (Table S2). The field strain S. littoralis larvae were collected from the local open field at Sharqia Governorate. They were transferred to the laboratory and reared for two successive generations as described above. The laboratory strain is reared 
in the laboratory for several successive generations away from any contamination with pesticides; so, it is guaranteed that it is free from any resistance to the action of pesticides. When experiments are conducted on it, the results of any treatment are assured of confidence; unlike the field strain that is randomly brought from the field where exposure to different pesticides is present. It is available and it is uncertain whether the field strain may enhance the resistance genes for the action of the treated substance or not; therefore, conducting experiments on the two strains gives additional dimensions in evaluating the tested toxicants.

\section{Actinobacteria fermentation and metabolites extraction}

The actinobacterial strains were cultured ( $2 \mu \mathrm{L}$ of spore suspension) in $50 \mathrm{~mL}$ sterilized starch casein broth and incubated at $28 \pm 2^{\circ} \mathrm{C}$ for 21 days with continuous shaking at $100 \mathrm{rpm}$. The mycelia were separated by centrifugation at $5000 \mathrm{rpm}$. The filtrates were extracted three successive times using equal volumes of ethyl acetate. The solvent layers were combined, concentrated, and evaporated to dryness using a rotary evaporator (HS-2005S-N, HAHN SHIN Scientific Co., Korea) at $40^{\circ} \mathrm{C}$. The dried extracts were redissolved in ethyl acetate to prepare a stock concentration of $100 \mathrm{mg} / \mathrm{mL}$ and stored at $4^{\circ} \mathrm{C}$ for bioactivity screening tests.

\section{Toxicity of ES2 metabolite to S. littoralis larvae}

The effects of the ES2 metabolite on the growth and development of the $S$. littoralis 4th instar larvae were evaluated at different concentrations. Toxicity was compared to that of spinetoram (Radiant ${ }^{\circledR} 12 \%$ SC $100 \mathrm{~cm}^{3} /$ feddans $\left(4200 \mathrm{~m}^{2}\right.$ ), a 2nd generation of the spinosyns, at $\mathrm{LC}_{50} 0.5 \mathrm{~mL} /$ liter (i.e. $0.05 \%$ concentration). The commercial Radiant SC 12\% (Dow Agros ciences; CAS Number: 187166-40-1) was obtained from the PPRI, Ministry of Agriculture, Egypt. The experimental design included normal group (untreated, receiving distilled water) and negative control group (receiving ethyl acetate). All bioassay assessments were duplicated (each replicate included four larvae) and performed under constant laboratory conditions. A detailed schema for the laboratory and field $S$. littoralis treatments is presented in Supplementary (Figure S1).

\section{Toxicity to 4th instar larvae of the laboratory S. littoralis strain (L-larvae)}

A series of four concentrations $(0.6,6,60,100 \mathrm{mg} / \mathrm{mL})$ of crude metabolites from the 70 actinobacteria strains were prepared. Newly molted 4 th instar L-larvae were starved for $3-4$ hours prior to the treatment to clear their alimentary canal and assure quick ingestion of treated leaves. Groups of larvae were transferred to $350 \mathrm{~mL}$ sterilized clean glass jars, and all jars were supplied with $7.0 \mathrm{~cm}$ filter paper to absorb any surplus moisture. Healthy, untreated leaves of castor, Ricinus communis L., were collected from the experimental field of the Plant Protection Research Institute. The leaves were washed, cut into equal discs using a cork borer, and impregnated with $50 \mu \mathrm{L}$ of the corresponding metabolite concentration (i.e. equivalent to $0.03,0.3,3$ and $5 \mu \mathrm{g} /$ disc) using a leaf dipping technique. The lethal effects (mortality \%) were recorded, daily, and corrected according to Abbott's formula (Abbott 1925). The treated insects were followed up, until the pupation stage. 
Toxicity to 4th instar larvae of the Field S. littoralis strain (F-larvae)

Metabolic extracts from seven actinobacterial strains, that showed potent activities against the laboratory 4th instar larvae, were further investigated for toxicity to the 4th instar F-larvae, at $100 \mathrm{mg} / \mathrm{mL}$ concentration. Lethality was recorded as detailed above.

\section{Phylogenetics of the promising actinobacteria strain}

The partial 16S rRNA gene sequence of Kitasatospora ES2 (which produced the metabolite of highest toxicity to the laboratory and field strains) was analyzed. DNA extraction was performed based on the salting-out method (Kieser et al. 2000), with an additional purification step using phenol/chloroform. The 16S rRNA gene of the strain was amplified using the universal primer set 27F (5'-AGA GTT TGA TCC TGG CTC AG-3') and 1492R (5'-GGT TAC CTT GTT ACG ACT T-3'). Amplification conditions were according to (Trujillo et al. 2010). Briefly: an initial denaturation step was performed for $9 \mathrm{~min}$ at $94^{\circ} \mathrm{C}$, followed by 30 cycles of denaturation for $1 \mathrm{~min}$ at $95^{\circ} \mathrm{C}$, annealing for $1 \mathrm{~min}$ at $55^{\circ} \mathrm{C}$ and extension for $2 \mathrm{~min}$ at $72^{\circ} \mathrm{C}$. A final extension step was performed for $10 \mathrm{~min}$ at $72^{\circ} \mathrm{C}$.

PCR product sequencing was performed at Macrogen "'tw Biotechnology, Ltd. (Korea) (https://dna.macrogen.com/eng/). The sequence obtained and those of its most closely related Streptomycetes spp., retrieved from GenBank, were aligned using BLASTN (Version: 2.9.0+) (Zhang et al. 2000). The maximum identity score sequences were selected and aligned using the multiple alignment program ClustalW (Thompson et al. 1997). The phylogenetic tree was established by the maximum likelihood method, 1000 bootstrap, Tamura 3-parameter model; constructed using MEGA11 (Tamura et al. 2021).

\section{Toxic effects Kitasatospora sp. ES2 crude metabolic extract (ES2)}

The $4^{\text {th }}$ larval instar of the laboratory S. littoralis strain (L-larvae) were exposed to ES2, the most potent strain, and investigated for morphological defects and histopathological and biochemical changes.

\section{Histopathological examinations of L-larvae}

Samples of the treated L-larvae and controls were collected at 72 hours post treatment. They were preserved in $3 \mathrm{~mL} 10 \%$ formaldehyde $(\mathrm{v} / \mathrm{v})$ in sterilized screw-capped tubes, prior to fixation, dehydration and embedding in paraffin wax. Serial sections, at five microns, were made with a microtome and mounted on clean slides using Mayer's albumin. The sections were stained with Ehrlich's hematoxylineosin (HE) (Ruiz et al. 2004). The histological longitudinal and transverse sections were examined under a light binocular stereomicroscope (NOVEL; NLCD-120, China) using two magnifications (100-X and 400$\mathrm{X})$.

\section{Biochemical assessments, Larvae-samples preparation}


Samples (groups of four) of the treated and control L-larvae were placed in clean screw-capped tubes and kept frozen overnight. The frozen samples were homogenized for three min in distilled water $(50 \mathrm{mg} / 1$

$\mathrm{mL}$ ) using a chilled glass Teflon tissue homogenizer (ST-2 Mechanic-Preczyina, Poland) surrounded with a crushed ice jacket. Then, they were centrifuged at $8000 \mathrm{rpm}$ for $15 \mathrm{~min}$ at $5^{\circ} \mathrm{C}$ in a refrigerated microcentrifuge (Hettich, Germany). The supernatants, used as enzyme extracts, were stored at $-20^{\circ} \mathrm{C}$ until use in biochemical assays. All biochemical measurements were performed in triplicates. A double beam UV spectrophotometer (Spectronic 1201, Milton Roy Co., USA) was used to measure the absorbance of colored substances. The total protein concentration was determined according to Bradford's method (Bradford 1976).

Acetylcholinesterase (AchE, EC 3.1.1.7) determination. The biochemical activity of acetylcholinesterase, a detoxification enzyme, was measured according to (Simpson et al. 1964), using acetylcholine bromide (AchBr) as a substrate. The samples were measured at $515 \mathrm{~nm}$ absorbance against a blank (ethanol in phosphate buffer, $\mathrm{pH}$ 8.0). The activity was expressed as $\mathrm{U} / \mathrm{mg}$ protein.

Protease (EC 3.4.21.112) determination. Proteolytic activity was measured as described by (Tatchell et al. 1972), with modifications, by measuring the increase in free amino acids split from a substrate protein (albumin) during 1 hour of incubation at $30^{\circ} \mathrm{C}$. Amino acids were colorimetrically assayed by ninhydrin reagent. The zero adjustment was performed at $570 \mathrm{~nm}$ against the reagent blank (100 $\mu \mathrm{L}$ distilled water). The amino acids were expressed as $\mu \mathrm{g} \mathrm{D}$, L-alanine/min/mg protein.

Lactate dehydrogenase ( $L D H, E C$ 1.1.1.27) determination. The $L D H$ activity was performed as described by (Diamantino et al. 2001). The zero adjustment was performed against buffer without substrate. The activity was expressed as $\mathrm{U} / \mathrm{mg}$ protein $(1 \mathrm{U}=1 \mu \mathrm{mol}$ substrate hydrolysed per minute).

\section{Non targeted metabolomics analysis}

Liquid chromatography, combined with quadrupole-time-of-flight high-definition mass spectrometry (LCQ-TOF-MS), was used to investigate the chemical constituents of the metabolites from Kitasatospora sp. ES2 strain. This technique is a powerful tool for the characterization of microbial compounds with similar structures, particularly in the analysis of natural products (Liu et al. 2010).

The study was conducted on a Triple TOF® $5600+$, Sciex system, Canada; pre-column $(0.5 \mu \mathrm{m} \times 3.0 \mathrm{~mm}$; Phenomenex Co., USA) and XBridge C18 column ( $3.5 \mu \mathrm{m}, 2.1 \times 50 \mathrm{~mm}$; Waters Co., USA) with two LC columns, in-line filter discs, at $40^{\circ} \mathrm{C}$. Detailed preparation and processing of the sample is provided in the Supplementary (Table S3). Based on their fragments, MasterView was used to define peaks using Build-in databases Data acquisition Analyst TF 1.7.1 software, Sciex). Using the Reaxys ChemDraw software, version 18.0.0.20 (https://www.reaxys.com), the cyromazine compound that can effectively target lethality to the larvae (Table. 1) was drawn.

\section{Molecular docking simulation}


Molecular docking aimed to illustrate the virtual mechanism of binding of some reported compounds used as insecticides towards acetylcholinesterase (AchE, PDB=4EY5), lactate dehydrogenase (LDH, $\mathrm{PDB}=1 \mathrm{LDG}$ ), and protease (SREBPs, PDB= 5GPD) target proteins, that were freely accessible through the protein data bank. Both proteins and ligands were prepared and optimized according to (Nafie et al. 2019), and the molecular docking study was carried out using MOE 2015-10 as the computational software. Each complex was analyzed for 2D interaction images were taken by using MOE visualizing tool. 3D interaction images were taken by Chimera (UCSF).

\section{Statistical analysis}

All data were formulated as means \pm standard error of the mean (SEM). Data was subjected to normality testing using Kolmogorov-Smirnov at 0.05 level. Accordingly, LDH, protease and AchE were parametric and parametric data analysis applied. One-way ANOVA was applied to assess the difference between treatment groups, ANOVA was followed by Duncan's Multiple Range tests (DMRTs) as a posthoc test at 0.05 level.

\section{Results}

\section{Toxicity of actinobacteria metabolites to S. littoralis larvae}

Toxicity of seventy actinobacteria metabolic extracts to the laboratory S. littoralis strain (L-larvae) was evaluated at four concentrations. We observed significant potent and immediate death of the treated larvae, using $100 \mathrm{mg} / \mathrm{ml}$ extracts from seven metabolic extracts, at 48 hours post-treatment (Table 2). However, using lower metabolite concentrations $(0.6,6$, and $60 \mathrm{mg} / \mathrm{mL})$, various levels of toxicity were observed. In the latter case, biological effects such as deformed individuals (Fig. 1b1) and abnormalities in pupae (Fig. 1b2, c) were observed and described as latent toxic effects, compared to the controls (Fig. 1a). Detailed toxic effects of the seventy metabolites on the L-larvae, at $100 \mathrm{mg} / \mathrm{ml}$ concentration, are shown in Supplementary (Table S4).

Table 2 Toxicity of the potent seven actinobacterial metabolic extracts to the $4^{\text {th }}$ instar larvae of $S$. littoralis laboratory and field strains, at concentration $100 \mathrm{mg} / \mathrm{mL}$. 


\begin{tabular}{|c|c|c|c|c|c|}
\hline \multicolumn{2}{|c|}{ Actinobacteria strain } & \multicolumn{2}{|c|}{ Laboratory strain mortality } & \multicolumn{2}{|c|}{ Field strain mortality } \\
\hline Code & genus & Immediate & Latent $^{b}$ & Immediate & Latent \\
\hline 11 & Nocardioides sp. & +++ & + & ++ & + \\
\hline 19 & Nocardioides $\mathrm{sp}$. & +++ & +++ & ++ & + \\
\hline 26 & Streptomyces sp. & +++ & +++ & na & ++ \\
\hline 53 & Kitasatospora ES2 & +++ & + & +++ & + \\
\hline 62 & Streptomyces sp. & +++ & +++ & na & na \\
\hline 67 & Pseudonocardia sp. & +++ & + & na & na \\
\hline 68 & Kitasatospora sp. & +++ & na & na & ++ \\
\hline \multicolumn{2}{|c|}{ Control } & - & - & - & - \\
\hline \multicolumn{2}{|c|}{ Solvent Control } & na & na & na & na \\
\hline \multicolumn{2}{|c|}{ Radiant Control } & +++ & na & +++ & na \\
\hline
\end{tabular}

Toxicity to the field strain is highlighted in grey. ( ${ }^{a}$, death within $72 \mathrm{hrs} ;{ }^{b}$, late death of larval/pupal stages; Control, normally fed $S$. littoralis larvae; Solvent Control, larvae received ethyl acetate solvent; Radiant Control, larvae received Radiant $12 \%$ SC).

,$+++ 30-50 \%$ mortality; ++, 10-25\% mortality; +, > $10 \%$ mortality of pupal stage; na, no activity.

Our screening has shown highest activities of 7 actinobacteria on the fourth instar larvae of $S$. littoralis laboratory strain (L-larvae); with five toxic to the field S. littoralis strain (F-larvae). Immediate lethal effects were recorded for metabolites produced by actinobacteria of the genera Kitasatospora and Nocardioides. While, latent effects (death after $>72 \mathrm{hrs}$.) were observed for Streptomyces and Kitasatospora strains. The latent effects varied between deaths of the larvae after five days of the treatment, to death of the resulted pupae (Table 2).

\section{Identification of Kitasatospora sp. ES2 strain}

Partial 16S rRNA gene sequence of Kitasatospora ES2, which produces the most potent metabolite against the laboratory and field larvae strains, has shown similarity to Streptomyces spp. at $\leq 96.69 \%$ (Table 3). The neighbor-joining phylogenetic tree illustrating the affiliation of Kitasatospora ES2 and representatives from its phylogenetically closest taxa is shown in Supplementary (Figure S2).

Table 3 Query coverage and similarity \% of Kitasatospora ES2, EMCC2291 (MH200991) to its closest type strains, based on the partial 16S rRNA gene sequence. 


\begin{tabular}{|llll|}
\hline Closest type strain & $\begin{array}{l}\text { NCBI accession } \\
\#\end{array}$ & $\begin{array}{l}\text { Query coverage } \\
(\%)\end{array}$ & $\begin{array}{l}\text { Similarity } \\
(\%)\end{array}$ \\
\hline Streptomyces coelicolor strain MLA-21 & HQ848083.1 & $97 \%$ & $95.70 \%$ \\
\hline $\begin{array}{l}\text { Streptomyces erythrogriseus strain LMG } \\
19406\end{array}$ & NR_042294.1 & $97 \%$ & $95.63 \%$ \\
\hline Streptomyces griseorubens strain UAE1-1 & MT883494.1 & $97 \%$ & $95.55 \%$ \\
\hline $\begin{array}{l}\text { Streptomyces griseoincarnatus strain JCM } \\
\text { 4381 }\end{array}$ & MT760527.1 & $90 \%$ & $96.08 \%$ \\
\hline Streptomyces griseorubens strain 173477 & EU570500.1 & $98 \%$ & $95.63 \%$ \\
\hline Streptomyces labedae strain NBRC 15864 & NR_041192.1 & $97 \%$ & $95.63 \%$ \\
\hline Streptomyces labedae strain AJR1 & MT463534.1 & $97 \%$ & $95.63 \%$ \\
\hline Streptomyces variabilis strain 173628 & EU593728.1 & $97 \%$ & $95.63 \%$ \\
\hline Streptomyces variabilis strain NRRL B-3984 & NR_043840.1 & $97 \%$ & $95.63 \%$ \\
\hline Streptomyces griseorubens strain JCM 4383 & MT760529.1 & $92 \%$ & $96.06 \%$ \\
\hline $\begin{array}{l}\text { Streptomyces griseorubens strain NBRC } \\
\text { 12780 }\end{array}$ & NR_041066.1 & $97 \%$ & $95.63 \%$ \\
\hline Streptomyces chartreusis strain NBRC 12753 & NR_118341.1 & $91 \%$ & $96.69 \%$ \\
\hline Streptomyces griseorubens strain UAE2 & MZ021577.1 & $97 \%$ & $95.63 \%$ \\
\hline $\begin{array}{l}\text { Streptomyces erythrogriseus strain NBRC } \\
\text { 14601 }\end{array}$ & NR_112438.1 & $90 \%$ & $96.23 \%$ \\
\hline Streptomyces matensis strain JCM 4277 & MT760503.1 & $90 \%$ & $96.40 \%$ \\
\hline Streptomyces althioticus strain JCM 4344 & MT760514.1 & $99 \%$ & \\
\hline
\end{tabular}

The 16S rRNA gene sequence of Kitasatospora ES2 is deposited in the GenBank database under the number (MH200991). The culture is deposited at Cairo MIRCEN Culture Collection as Kitasatospora sp. ES2 EMCC2291; and the method of product application is registered for patency at the Egyptian Patent Office, patent No. $729 / 2019$.

\section{Toxicity of ES2 metabolite to the treated larvae}

Kitasatospora ES2 has caused $50 \%$ death in the L-larvae after 48 hours post-treatment. Also, some toxic effects have appeared in the treated larvae after 72 hours; those were considered latent effects. It is noteworthy that, some larvae failed to pupate from the larval stage to the pupal stage, leading to the production of larval-pupal or pupal-larval intermediates, as shown in (Fig. 1). The cuticle layers were distorted in the larvae treated with both ES2 (Fig. 2d) and Radiant (Fig. 2g), compared to the untreated 
control (Fig. 2a, b). Larvae that were treated with the ES2 have shown obviously higher degeneration and fissures in the muscles (Fig. 2c, d, e, f), than those subjected to the Radiant treatment (Fig. 2g). ES2 has, also, caused deformations (Fig. 2c, d, e, f), vacuolization of the hypodermal layer (Fig. 2d, e, f), and separation of the hypodermis from the cuticle layer (Fig. 2c, e). However, decomposition in the hypodermal cells of occurred only in the larvae treated with Radiant SC 12\% (Fig. 2g). ES2 has caused obvious gastrointestinal damages in the larval midgut tissue of $S$. littoralis, as compared to the control (Fig. 3a, b). These damages included: vacuolization (Fig. 3c, d, e), degeneration and necrosis of the epithelial cells and destruction of the cells and their boundaries (Fig. 3c, d, e, f). The microscopically observed changes were more severe than those observed in the Radiant-treated larvae (Fig. 3g). Separations of the basement and peritrophic membranes were, similarly, observed for both ES2 (Fig. 3e, f) and Radiant (Fig. 3g) treatments.

The application of ES2 and Radiant at 100 and $5 \mathrm{mg} / \mathrm{mL}$, respectively, has caused highly significant reductions in lactate dehydrogenase (LDH) and protease activities $(p \leq 0.01)$, while acetylcholinesterase (AchE) activity was not significantly changed, compared to the control. LDH activity in the untreated (control) larvae was $28.40 \pm 0.888 \mathrm{U} / \mathrm{mg}$ protein, and it has been reduced by $47 \%$ and $16 \%$, using ES2 and Radiant treatments, respectively. While, the reductions in protease activity were almost similar after both treatment $(37.00 \pm 2.081$ and $30.33 \pm 0.881 \mu \mathrm{g}$, L-alanine/min/mg protein for ES2 and Radiant, respectively), as shown in Table 4. The biochemical measurements, in our study, served to provide a preliminary understanding of the basis of ES2 toxicity.

Table 4 Lactate dehydrogenase (LDH), protease and acetylcholinesterase (AchE) activities of the laboratory S. littoralis treated with Kitasatospora ES2 crude metabolite. 


\begin{tabular}{|c|c|c|c|}
\hline Treatment & $\begin{array}{l}\text { LDH } \\
\text { (Ux } 10^{3} / \mathrm{mg} \\
\text { protein) }\end{array}$ & $\begin{array}{l}\text { Protease } \\
\text { (ug } D, L \text {-alanine } / \mathrm{min} / \mathrm{mg} \\
\text { protein) }\end{array}$ & $\begin{array}{l}\text { AchE } \\
\text { (ug AchBr/min/mg } \\
\text { protein) }\end{array}$ \\
\hline $\begin{array}{l}\text { Normal } \\
\text { distilled water }\end{array}$ & $28.4 \pm 0.89 a$ & $101.66 \pm 3.84 \mathbf{a}$ & $2.40 \pm 0.09 a$ \\
\hline $\begin{array}{l}\text { Negative } \\
\text { Control } \\
\text { Ethyl acetate }\end{array}$ & $26.42 \pm 0.68 \mathbf{a}$ & $92.33 \pm 1.45 \mathbf{b}$ & $2.15 \pm 0.09 a$ \\
\hline $\begin{array}{l}\text { Radiant } \\
(0.05 \%)\end{array}$ & $23.8 \pm 0.62 \mathbf{b}$ & $30.33 \pm 0.88 \mathbf{c}$ & $2.31 \pm 0.06 a$ \\
\hline $\begin{array}{l}\text { ES2 Metabolite } \\
(100 \mathrm{mg} / \mathrm{mL})\end{array}$ & $15.06 \pm 0.54 c$ & $37.00 \pm 2.08 \mathrm{c}$ & $2.16 \pm 0.05 a$ \\
\hline \multicolumn{4}{|l|}{ ANOVA- 1 way } \\
\hline F-ratio & 72.25 & 247.08 & 2.69 \\
\hline$p$-value & $<0.001^{\star \star \star}$ & $0.001 * \star \star$ & $>0.05 \mathrm{NS}$ \\
\hline \multicolumn{4}{|c|}{ Data expressed as Mean \pm S. E. $* * *=p \leq 0.01 \mathrm{NS}=$ non-Significant } \\
\hline
\end{tabular}

\section{Structure analysis and Molecular docking simulation of ES insecticidal activity}

LC-Q-TOF-MS analysis showed three insecticidal compounds as key constituents of the metabolic extract from Kitasatospora sp. ES2 EMCC2291: 4-nitrophenol, cyromazine and diazinon (Supplementary, Table S5). These compounds were chosen based on their surveyed activity as pesticides, and their structures are structurally highlighted in Fig. (4), showing the aromatic, polar, and nonpolar moieties. They were docked and visualized inside the acetylcholinesterase, lactate dehydrogenase, and protease proteins to highlight their virtual mechanism of binding in terms of binding energy and interactions. The compounds were properly docked inside the active sites of proteins with good binding energies ranging from -11.13 to $-14.67 \mathrm{Kcal} / \mathrm{mol}$. As seen in Fig. (5), compound cyromazine formed good binding interactions through its active pharmacophoric groups with the key amino acids of the tested three proteins. Additionally, the interactions for the other compounds inside the tested targets were supported (Supplementary, Figure S3). The molecular docking studies, agree with the experimental results enhancing the idea of their insecticide activity through acetylcholinesterase, lactate dehydrogenase, and protease inhibition.

\section{Discussion}


The lepidopterous pest $S$. littoralis has developed resistance due to the intensive pesticide use (Rehan and Freed 2014), imposing the need for novel pesticide compounds. This work aimed to evaluate the insecticidal effect of the secondary metabolites of actinobacteria strains from the microbiome of six medicinal plant species in the World Heritage Site of Saint Catherine, Egypt.

Notably, all the actinobacteria strains originated from Artemisia herba-alba and A. judaica plants, have shown high toxicity to the 4th instar larvae of $S$. littoralis. Previous studies have shown high insecticidal activities of essential oils from both plants against coleopteran pests, such as Orysaephilus surinamensis (Bachrouch et al. 2015) and Tribolium casteneum (Deb and Kumar 2020). Giving the evidence that endophytes can produce the same bioactive chemicals as their host plants (Kouipou Toghueo and Boyom 2019), this study represents the first illustration of insecticidal activity of the microbiome in Artemisia spp.

The partial 16S rRNA gene sequence of Kitasatospora sp. ES2, which produces the most potent metabolite against the laboratory and field larvae strains, showed low similarity levels with Streptomyces and Kitasatospora spp. in the available database. Since the guidelines by Strejcek et al. (2018) recommended similarity $\geq 97 \%$ to be considered as the same species, it is more likely that $K$. sp. ES2 represents a novel species. The difficulties to phylogenetically affiliate the ES2 strain within the currently validated species is expected because only twenty-three Kitasatospora species are, currently, published as validly names (Takahashi 2017). However, our earlier phenotypic and chemotaxonomic analysis of this strain has shown its affiliation in the genus Kitasatospora (El-Shatoury et al. 2013). Future analysis of the complete 16S RNA gene sequence of $K$. sp. ES2 strain could clarify its taxonomic position.

Notably, the results indicated significantly strong effect of ES2 in LDH inhibition; that effect was about 3times higher than the Radiant. LDH is an important glycolytic enzyme involved in carbohydrate metabolism and is a marker for reduced metabolism in the insect (Diamantino et al., 2001). This result compares well with other studies on the LDH inhibition by natural microbial products. For example, Nathan et al. (2006) demonstrated $20 \%$ suppression of the LDH activity in the fourth larval instar Cnaphalocrocis medinalis (the rice leaf folder), following exposure to $3 \mu \mathrm{g} / \mathrm{mL}$ of Bacillus thuringiensis bioinsecticide. A field experiment showed 55.7\% LDH inhibition, when 5th instar larvae of S. littoralis were exposed to Radiant, at 40 liters/feddan (Fahmy and Dahi 2009), causing low nutritional efficiency and less subsequent vital activities in the larvae. The results, also, indicated highly significant inhibitory effect of both ES2 and Radiant on protease (64 - 70\% inhibition). Proteases are involved in the glycolysis process and the neural signals transmission in insects (Cheng et al. 1999). Therefore, we hypothesize that ES2 may act on the insect metabolism and causes death by disrupting the glycolysis process due to inhibition of LDH and protease enzymes. Radiant causes death due to disruption of the nervous system (Krämer and Schirmer 2007), While the main action of ES2 is not expected to target the nervous system, because it has caused nonsignificant changes in acetylcholinesterase activity. Acetylcholinesterase is the primary cholinesterase in the pest body that plays a major role the transmission of the nerve signals (Casida and Durkin 2013). ES2 may, thus, have a different mode of action than that of spinetoram. 
It is reasonable that, the toxicity of ES2, morphological defects and histopathological deformities in the insect is attributed to its unique mixture of several compounds with special regard to cyromazine, as a key constituent. All the previous studies on cyromazine have used a chemically synthesized formula of the compound. Cyromazine has been widely used for pest control in agricultural crops and public health management systems (Subramanian and Shankarganesh 2016). It is considered as a molt inhibitor, by interfering with cuticle formation in the insect (Pener and Dhadialla 2012). This effect on cuticle, perhaps, was responsible for the symptoms of mortality in S. littoralis 4 th instar larvae in our investigations. The morphological and histopathological examination of the midgut tissue supports this hypothesis. Where, the muscle degeneration, fissures and the gastrointestinal damage associated with the ES2 were stronger than those caused by Radiant. The observed lesions in the body wall cuticle may be a consequence of excessive internal pressure. Feeding on ES2 may have been disrupted the development because the body wall could not expand to accommodate the increased body mass. Additionally, movement may have been impaired because excess pressure in the haemolymph prevents the caterpillar's hydrostatic skeleton from normal function. These symptoms are suggested to cause the observed larval mortality and the formation of intermediate individuals in our experiment. Recent studies which characterize secondary metabolites from actinobacteria, shows insect growth disrupting activities against various species of Spodoptera. These include polyketides that inhibit insect growth (Arasu et al. 2013), juvenile hormone antagonists (Kim et al. 2020) and chitin synthesis inhibitors (Usuki et al. 2008). However, this is the first report on natural synthesis of cyromazine by actinobacteria.

Despite the similarities between ES2 and Radiant regarding their effects on Protease and AchE activities, they are suggested to have different mode of actions for many reasons. First, ES2 is relatively polar and water-soluble, preliminary data shown, which is a fundamental and promising difference than the spinosyn class (Crouse et al. 2001), for future applications. Second, ES2 didn't show overexcitation symptoms of neurons, as reported when using Radiant (Orr et al. 2009). Third, ES2 crude metabolite has 4-nitrophenol, cyromazine and diazinon as major constituents. Fourth, ES2 had three-times more inhibitory effect on LDH activity than Radiant. However, it should be notified that, comparison of the inhibitory extent may not be reasonable because of the crude nature of ES2 vs Radiant SC $12 \%$. The latter is a pure mixture of spinosyn $\mathrm{J}$ and spinosyn $\mathrm{L}$. For all the above, it is reasonable to suggest that Kitasatospora ES2 strain may possess the prospect to generate a structurally novel class of alternatives biocontrol agents against lepidopterous pests such as $S$. littoralis.

In conclusion, endophytic actinobacteria from wild medicinal plants represent a promising source for biocontrol agents. Metabolites from Kitasatospora sp. ES2 can cause direct and latent effects on the 4th instar larvae of the cotton leafworm S. littoralis. The phylogenetic analysis of $K$. sp. ES2 strain indicated its novelty. The toxicity of ES2 to $S$. littoralis, and the morphological defects and histopathological deformities may be attributed to its unique mixture of several compounds with special regard to cyromazine (a molt inhibitor), 4-nitrophenol, and diazinon as major constituents. Molecular docking confirms the experimental results of ES2 insecticide activity through acetylcholinesterase, lactate dehydrogenase, and protease inhibition. 
This is the first illustration of insecticidal activity of the Artemisia spp. microbiome, and the first report on a natural cyromazine synthesized by actinobacteria. In our next publication, we anticipate reporting the complete chemical properties of the "active ingredients" produced by Kitasatospora sp. ES2 and their expected targets, based on bioinformatic and molecular docking studies.

\section{Declarations}

\section{Acknowledgments}

The authors would like to thank Prof. Hesham Abdulla and Miss Fatma Mansour at the Faculty of Science, Suez Canal University; and Dr. Hend Mohamed Sabry at Plant Protection Research Institute, Agricultural Research Centre, for their invaluable assistance during this work.

\section{Author contribution}

$\mathrm{HM}, \mathrm{MK}$ and SE conceived, designed research and supervised the work. MD and MN conducted experiments and analyzed data. MD, HM, MK and SE wrote the manuscript. All authors read and approved the manuscript.

\section{Funding}

This work is partially funded by Suez Canal University, Rally Project Fund, 1/2020.

\section{Data availability}

Partial 16S rRNA gene sequence of Kitasatospora ES2 is deposited in the GenBank database (No. MH200991). The culture is deposited at Cairo MIRCEN Culture Collection, accession No. Kitasatospora $s p$. ES2 EMCC2291. The method of product application is registered at the Egyptian Patent Office, patent No. $729 / 2019$.

\section{Ethics approval}

This article does not contain any studies with human participants, but included studies for insects, and all protocols and procedures employed in insect studies were ethically reviewed and approved by Suez Canal University's Ethical Committee.

\section{Consent for publication}

All authors have read and approved the manuscript for submission and publication

\section{Conflict of interest}

The authors declare no competing interests. 


\section{References}

1. Abbott WS (1925) A method of computing the effectiveness of an insecticide. J econ Entomol 18(2):265-267

2. Arasu MV, Al-Dhabi NA, Saritha V, Duraipandiyan V, Muthukumar C, Kim S-J (2013) Antifeedant, larvicidal and growth inhibitory bioactivities of novel polyketide metabolite isolated from Streptomyces sp. AP-123 against Helicoverpa armigera and Spodoptera litura. BMC Microbiol 13:105-105 doi:10.1186/1471-2180-13-105

3. Bachrouch O, Ferjani N, Haouel S, Jemâa JMB (2015) Major compounds and insecticidal activities of two Tunisian Artemisia essential oils toward two major coleopteran pests. Ind Crops Prod 65:127133 doi:https://doi.org/10.1016/j.indcrop.2014.12.007

4. Bradford MM (1976) A rapid and sensitive method for the quantitation of microgram quantities of protein utilizing the principle of protein-dye binding. Anal Biochem 72(1):248-254 doi:https://doi.org/10.1016/0003-2697(76)90527-3

5. Casida JE, Durkin KA (2013) Anticholinesterase insecticide retrospective. Chem Biol Interact 203(1):221-225 doi:10.1016/j.cbi.2012.08.002

6. Cheng D, Espenshade PJ, Slaughter CA, Jaen JC, Brown MS, Goldstein JL (1999) Secreted Site-1 Protease Cleaves Peptides Corresponding to Luminal Loop of Sterol Regulatory Element-binding Proteins*. J Biol Chem 274(32):22805-22812 doi:https://doi.org/10.1074/jbc.274.32.22805

7. Crouse GD, Sparks TC, Schoonover J, Gifford J, Dripps J, Bruce T, Larson LL, Garlich J, Hatton C, Hill RL, Worden TV, Martynow JG (2001) Recent advances in the chemistry of spinosyns. Pest Manag Sci 57(2):177-85 doi:10.1002/1526-4998(200102)57:2<177::Aid-ps281>3.0.Co;2-z

8. Deb M, Kumar D (2020) Bioactivity and efficacy of essential oils extracted from Artemisia annua against Tribolium casteneum (Herbst. 1797) (Coleoptera: Tenebrionidae): An eco-friendly approach. Ecotoxicol Environ Saf 189:109988 doi:https://doi.org/10.1016/j.ecoenv.2019.109988

9. Diamantino TC, Almeida E, Soares AMVM, Guilhermino L (2001) Lactate dehydrogenase activity as an effect criterion in toxicity tests with Daphnia magna straus. Chemosphere 45(4):553-560 doi:https://doi.org/10.1016/S0045-6535(01)00029-7

10. El-Shatoury SA, El-Kraly OA, Trujillo ME, El-Kazzaz WM, El-Din E-SG, Dewedar A (2013) Generic and functional diversity in endophytic actinomycetes from wild Compositae plant species at South Sinai Egypt. Res Microbiol 164(7):761-769 doi:10.1016/j.resmic.2013.03.004

11. Fahmy M, Dahi H (2009) Changes in detoxifying enzymes and carbohydrate metabolism associated with spinetoram in two field-collected strains of Spodoptera littoralis (Biosd.). Egypt Acad J Biol Sci, F Toxicol Pest Control 1(1):17-26 doi:10.21608/eajbsf.2009.17549

12. Hazaa M, Alm-Eldin M, Ibrahim A-E, Elbarky N, Salama M, Sayed R, Sayed W (2020) Biosynthesis of Silver Nanoparticles using Borago officinslis leaf extract, characterization and larvicidal activity against cotton leaf worm, Spodoptera littoralis (Bosid). Int J Trop Insect Sci doi:10.1007/s42690020-00187-8 
13. Kieser T, Bibb MJ, Buttner MJ, Chater KF, Hopwood DA (2000) Practical Streptomyces genetics. The John Innes Foundation, Norwich

14. Kim HJ, White-Phillip JA, Ogasawara Y, Shin N, Isiorho EA, Liu H-w (2010) Biosynthesis of Spinosyn in Saccharopolyspora spinosa: Synthesis of Permethylated Rhamnose and Characterization of the Functions of SpnH, Spnl, and SpnK. J Am Chem Soc 132(9):2901-2903 doi:10.1021/ja910223x

15. Kim JH, Choi JY, Park DH, Park D-J, Park MG, Kim SY, Ju YJ, Kim JY, Wang M, Kim C-J, Je YH (2020) Isolation and characterization of the insect growth regulatory substances from actinomycetes. Comp Biochem Physiol C Toxicol Pharmacol 228:108651 doi:https://doi.org/10.1016/j.cbpc.2019.108651

16. Kouipou Toghueo RM, Boyom FF (2019) Endophytes from ethno-pharmacological plants: Sources of novel antioxidants- A systematic review. Biocatal Agric Biotechnol 22:101430 doi:https://doi.org/10.1016/j.bcab.2019.101430

17. Krämer W, Schirmer U (2007) Modern crop protection compounds, 3 volume set. John Wiley \& Sons Ltd

18. Kumar S, Stecher G, Tamura K (2016) MEGA7: Molecular Evolutionary Genetics Analysis Version 7.0 for Bigger Datasets. Molecular biology and evolution 33(7):1870-4 doi:10.1093/molbev/msw054

19. Kvakkestad V, Sundbye A, Gwynn R, Klingen I (2020) Authorization of microbial plant protection products in the Scandinavian countries: A comparative analysis. Environ Sci Policy 106:115-124 doi:https://doi.org/10.1016/j.envsci.2020.01.017

20. Liu CW, Lu YY, Yang ZZ, Xing YY, Xi T (2010) Rapid screening and characterization of metabolites from a marine-derived actinomycete by high-performance liquid chromatography coupled with electrospray ionization quadrupole time-of-flight mass spectrometry. Rapid Commun Mass Spectrom 24(23):3413-8 doi:10.1002/rcm.4744

21. Nathan SS, Kalaivani K, Murugan K (2006) Effect of biopesticides on the lactate dehydrogenase (LDH) of the rice leaffolder, Cnaphalocrocis medinalis (Guenée) (Insecta: Lepidoptera: Pyralidae). Ecotoxicol Environ Saf 65(1):102-107 doi:https://doi.org/10.1016/j.ecoenv.2005.05.021

22. Orr N, Shaffner A, Richey K, Crouse G (2009) Novel mode of action of spinosad: Receptor binding studies demonstrating lack of interaction with known insecticidal target sites. Pestic Biochem Phys 95:1-5 doi:10.1016/j.pestbp.2009.04.009

23. Pasiecznik NM, Smith IM, Watson GW, Brunt AA, Ritchie B, Charles LMF (2005) CABI/EPPO distribution maps of plant pests and plant diseases and their important role in plant quarantine. Bulletin OEPP 35(1):1-7 doi:10.1111/j.1365-2338.2005.00815.x

24. Pener MP, Dhadialla TS (2012) Chapter One - An Overview of Insect Growth Disruptors; Applied Aspects. In: Dhadialla TS (ed) Advances in Insect Physiology. vol 43. Academic Press, pp 1-162

25. Rang J, He H, Yuan S, Tang J, Liu Z, Xia Z, Khan TA, Hu S, Yu Z, Hu Y, Sun Y, Huang W, Ding X, Xia L (2020) Deciphering the Metabolic Pathway Difference Between Saccharopolyspora pogona and Saccharopolyspora spinosa by Comparative Proteomics and Metabonomics. Front Microbiol 11(396) doi:10.3389/fmicb.2020.00396 
26. Rehan A, Freed S (2014) Selection, mechanism, cross resistance and stability of spinosad resistance in Spodoptera litura (Fabricius) (Lepidoptera: Noctuidae). Crop Prot 56:10-15 doi:https://doi.org/10.1016/j.cropro.2013.10.013

27. Ruiz LM, Segura C, Trujillo J, Orduz S (2004) In vivo binding of the Cry11Bb toxin of Bacillus thuringiensis subsp. medellin to the midgut of mosquito larvae (Diptera: Culicidae). Memorias do Instituto Oswaldo Cruz 99(1):73-9 doi:10.1590/s0074-02762004000100013

28. Shi Y, Zhang X, Lou K (2013) Isolation, characterization, and insecticidal activity of an endophyte of drunken horse grass, Achnatherum inebrians. J Insect Sci 13(1) doi:10.1673/031.013.15101

29. Simpson DR, Bull DL, Lindquist DA (1964) A Semimicrotechnique for the Estimation of Cholinesterase Activity in Boll Weevils1. Ann Entomol Soc Am 57(3):367-371 doi:10.1093/aesa/57.3.367

30. Strejcek M, Smrhova T, Junkova P, Uhlik O (2018) Whole-Cell MALDI-TOF MS Versus 16S rRNA Gene Analysis for Identification and Dereplication of Recurrent Bacterial Isolates. Front Microbiol 9:1294 doi:10.3389/fmicb.2018.01294

31. Subramanian S, Shankarganesh K (2016) Chapter 20 - Insect Hormones (as Pesticides). In: Omkar (ed) Ecofriendly Pest Management for Food Security. Academic Press, San Diego, pp 613-650

32. Takahashi Y (2017) Genus Kitasatospora, taxonomic features and diversity of secondary metabolites. J Antibiot 70(5):506-513 doi:10.1038/ja.2017.8

33. Tamura K., Stecher G., and Kumar S. (2021) MEGA 11: Molecular Evolutionary Genetics Analysis Version 11. Mol Biol Evol 38(7):3022-3027 doi.org/10.1093/molbev/msab120

34. Tanvir R, Sheikh AA, Javeed A (2019) Chapter 11 - Endophytic Actinomycetes in the Biosynthesis of Bioactive Metabolites: Chemical Diversity and the Role of Medicinal Plants. In: Atta ur R (ed) Studies in Natural Products Chemistry. vol 60. Elsevier, pp 399-424

35. Tatchell RJ, Araman SF, Boctor FN (1972) Biochemical and physiological studies of certain ticks (ixodoidea). Zeitschrift für Parasitenkunde 39(4):345-350 doi:10.1007/BF00329096

36. Thompson JD, Gibson TJ, Plewniak F, Jeanmougin F, Higgins DG (1997) The CLUSTAL_X windows interface: flexible strategies for multiple sequence alignment aided by quality analysis tools. Nucleic Acids Res 25(24):4876-82 doi:10.1093/nar/25.24.4876

37. Trujillo ME, Alonso-Vega P, Rodríguez R, Carro L, Cerda E, Alonso P, Martínez-Molina E (2010) The genus Micromonospora is widespread in legume root nodules: the example of Lupinus angustifolius. ISME J 4(10):1265-1281 doi:10.1038/ismej.2010.55

38. Usuki H, Nitoda T, Ichikawa M, Yamaji N, Iwashita T, Komura H, Kanzaki H (2008) TMGchitotriomycin, an Enzyme Inhibitor Specific for Insect and Fungal $\beta$-N-Acetylglucosaminidases, Produced by Actinomycete Streptomyces anulatus NBRC 13369. J Am Chem Soc 130(12):4146-4152 doi:10.1021/ja077641f

39. White JF, Kingsley KL, Zhang Q, Verma R, Obi N, Dvinskikh S, Elmore MT, Verma SK, Gond SK, Kowalski KP (2019) Review: Endophytic microbes and their potential applications in crop management. Pest Manag Sci 75(10):2558-2565 doi:10.1002/ps.5527 
40. Zhang Z, Schwartz S, Wagner L, Miller W (2000) A greedy algorithm for aligning DNA sequences. J Comput Biol 7(1-2):203-14 doi:10.1089/10665270050081478

41. Zhao H, Yang A, Zhang N, Li S, Yuan T, Ding N, Zhang S, Bao S, Wang C, Zhang Y, Wang X, Hu L (2020) Insecticidal Endostemonines A-J Produced by Endophytic Streptomyces from Stemona sessilifolia. J Agric Food Chem 68(6):1588-1595 doi:10.1021/acs.jafc.9b06755

\section{Figures}

a)

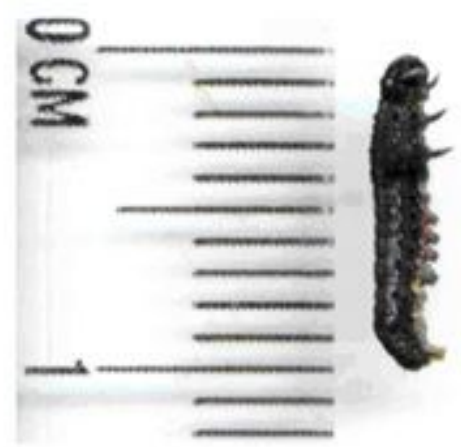

b)

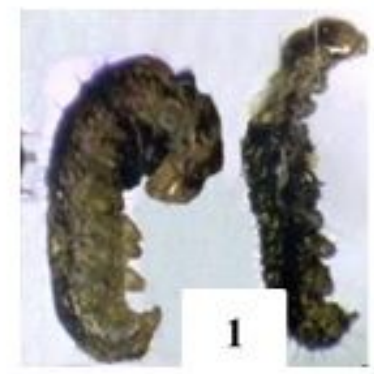

c)

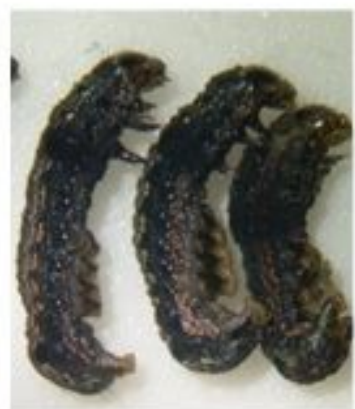

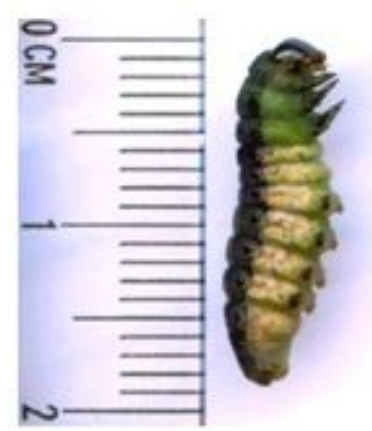
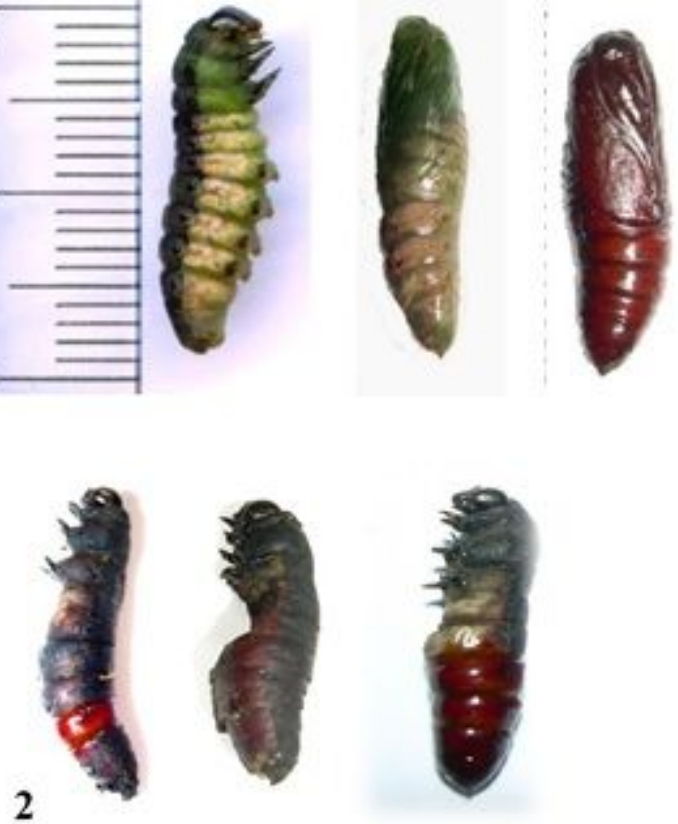

\section{Figure 1}

Lethality and developmental defects in 4th instar laboratory S. littoralis larvae after exposure to Kitasatospora ES2 metabolites a) Control S. littoralis (from left: larva, prepupa, young pupa and mature pupa). b) Effects of the Kitasatospora ES2 crude metabolite; various direct toxicity on larvae (1) and latent effects on pupae (2). c) Morphological effects of the commercial product Radiant SC $12 \%$ on larvae. 


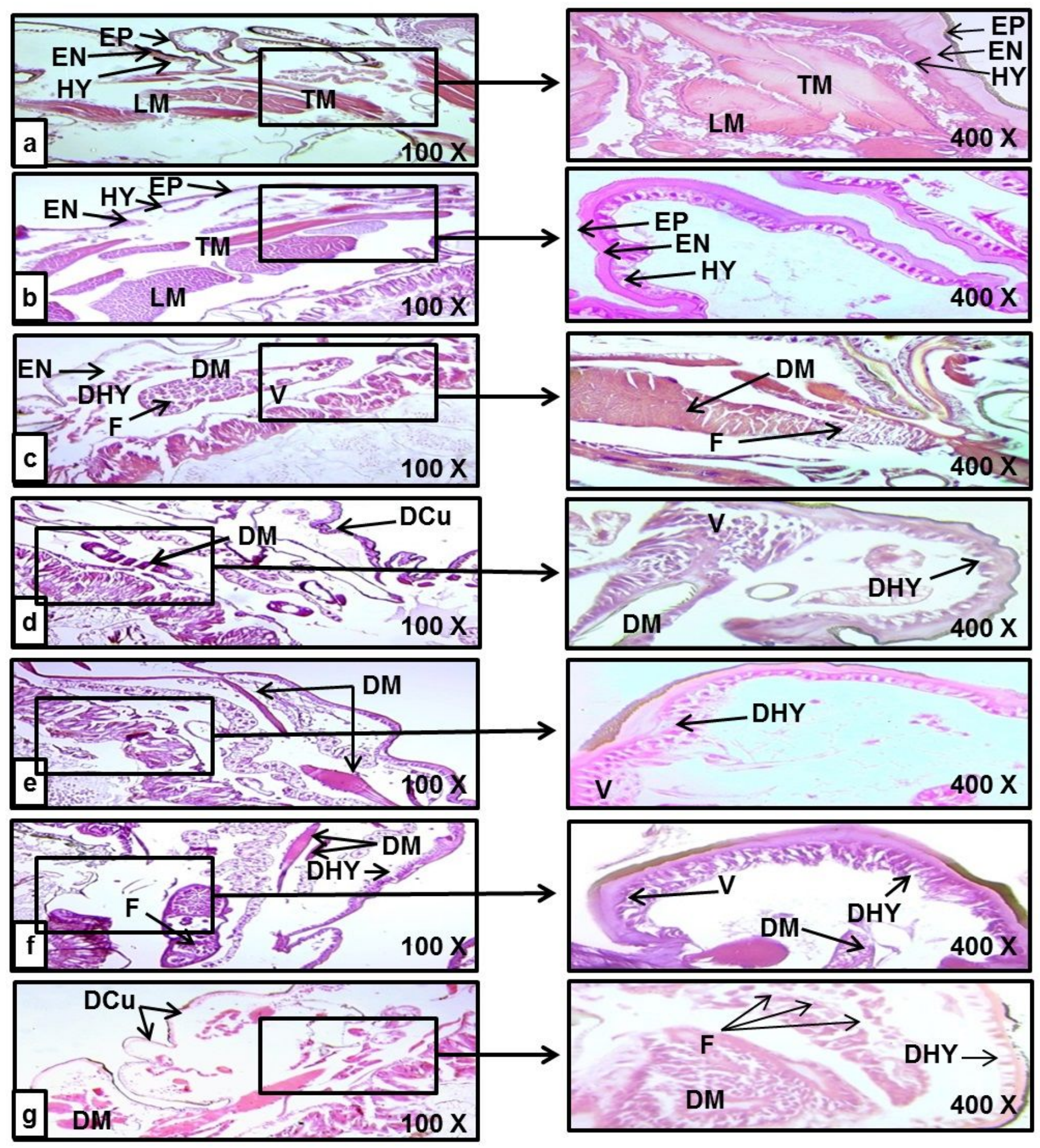

Figure 2

Light micrographs of longitudinal sections of histopathological deformities on the S. littoralis larval cuticle layer three days post treatment with Kitasatospora ES2 crude metabolite, showing muscle deformities (100 \& $400 \times \mathrm{H} \& \mathrm{E})$. a) Control larvae treated with water; b) Negative control larvae treated with ethyl acetate solvent; c-f) Larvae treated with the Kitasatospora ES2 crude metabolite; and (g) Positive control larvae treated with Radiant 12 \% SC. [DCu, degenerated cuticle; DHY, deformed 
hypodermis; DM, degenerated muscles; EN, endocuticle; EP, epicuticle; F, fissures in muscles; $\mathrm{HY}$, hypodermis; LM, longitudinal muscles; TM, transverse muscles; $\mathrm{V}$, vacuoles].
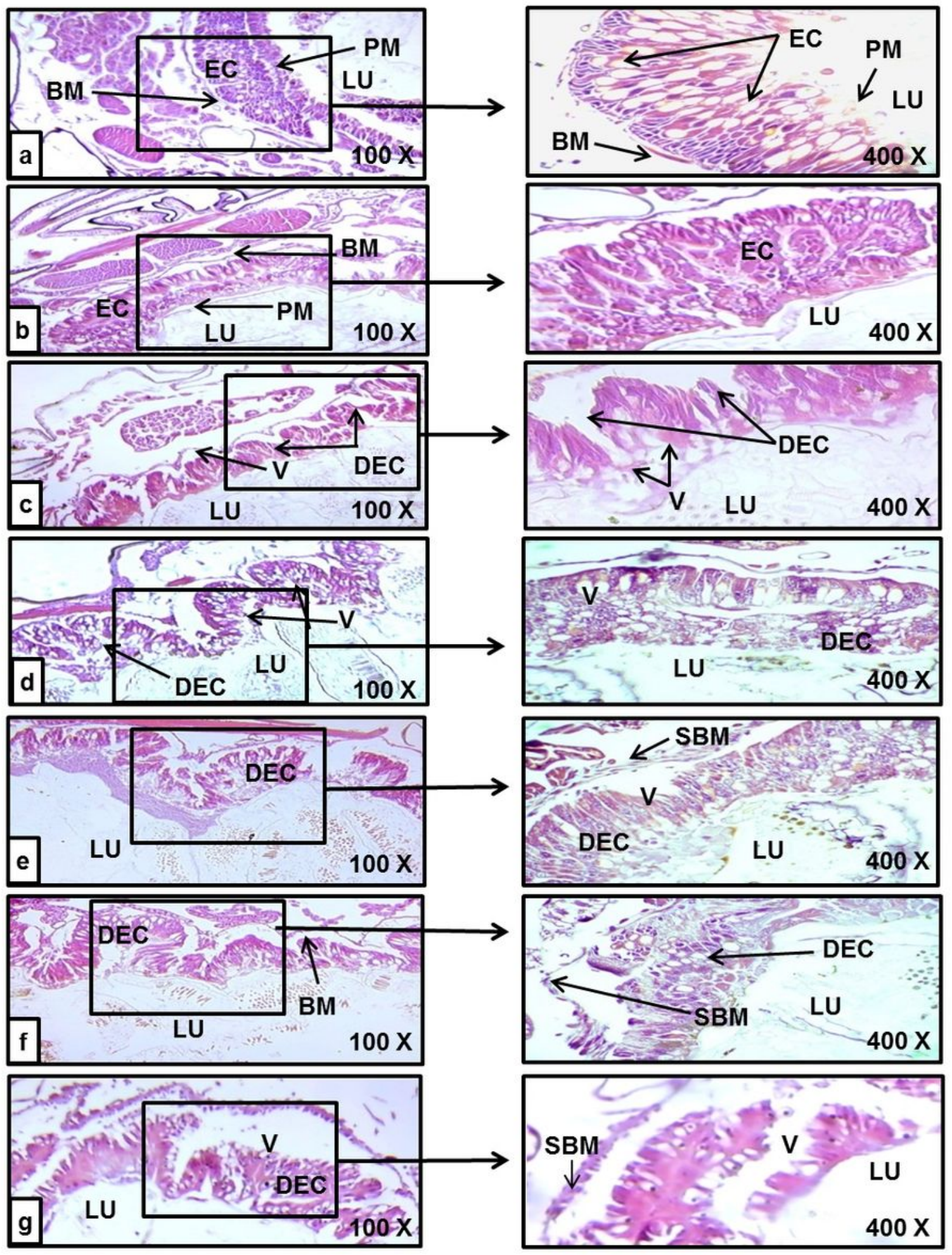

Figure 3

Light micrographs of transverse sections of histopathological deformities in S. littoralis larval midgut tissue after three days posttreatment with Kitasatospora ES2 crude metabolite (100 \& $400 \times \mathrm{H} \& \mathrm{E})$. a) Control larvae treated with water; b) Negative control larvae treated with ethyl acetate solvent; c-f) Larvae 
treated with the Kitasatospora ES2 crude metabolite; and g) Positive control larvae treated with Radiant $12 \%$ SC. [BM, basement membrane; DEC, degenerated epithelial cells; EC, epithelial cells; LU, lumen; PM, peritrophic membrane; SBM, separated basement membrane; $\mathrm{V}$, vacuoles.].

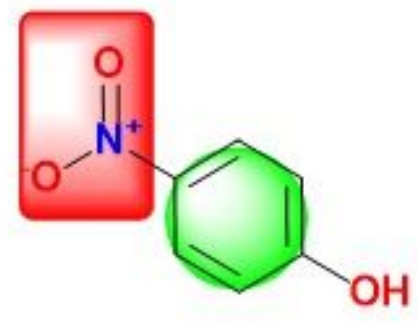

4-Nitrophenol

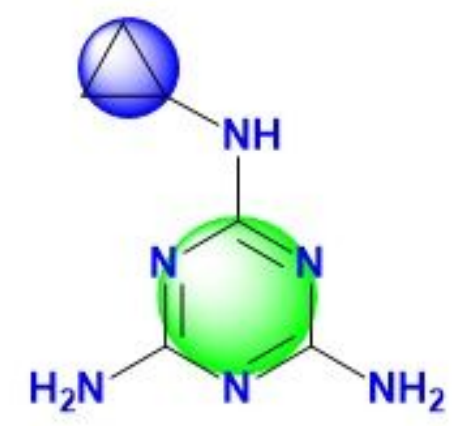

Cyromazine

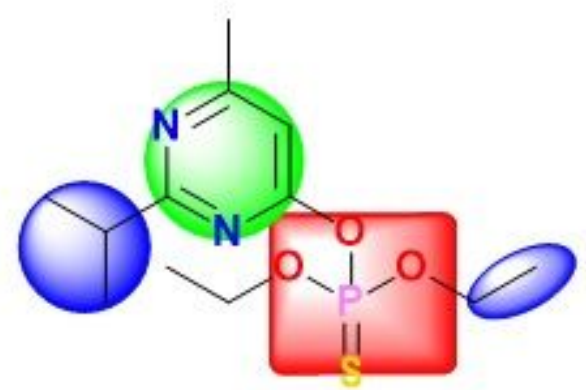

Diazinon

\section{Aromatic moeity}

Polar moeity

Non-polar moeity

\section{Figure 4}

Highlighted pharmacophoric regions for the compounds with reported insecticide activities. 

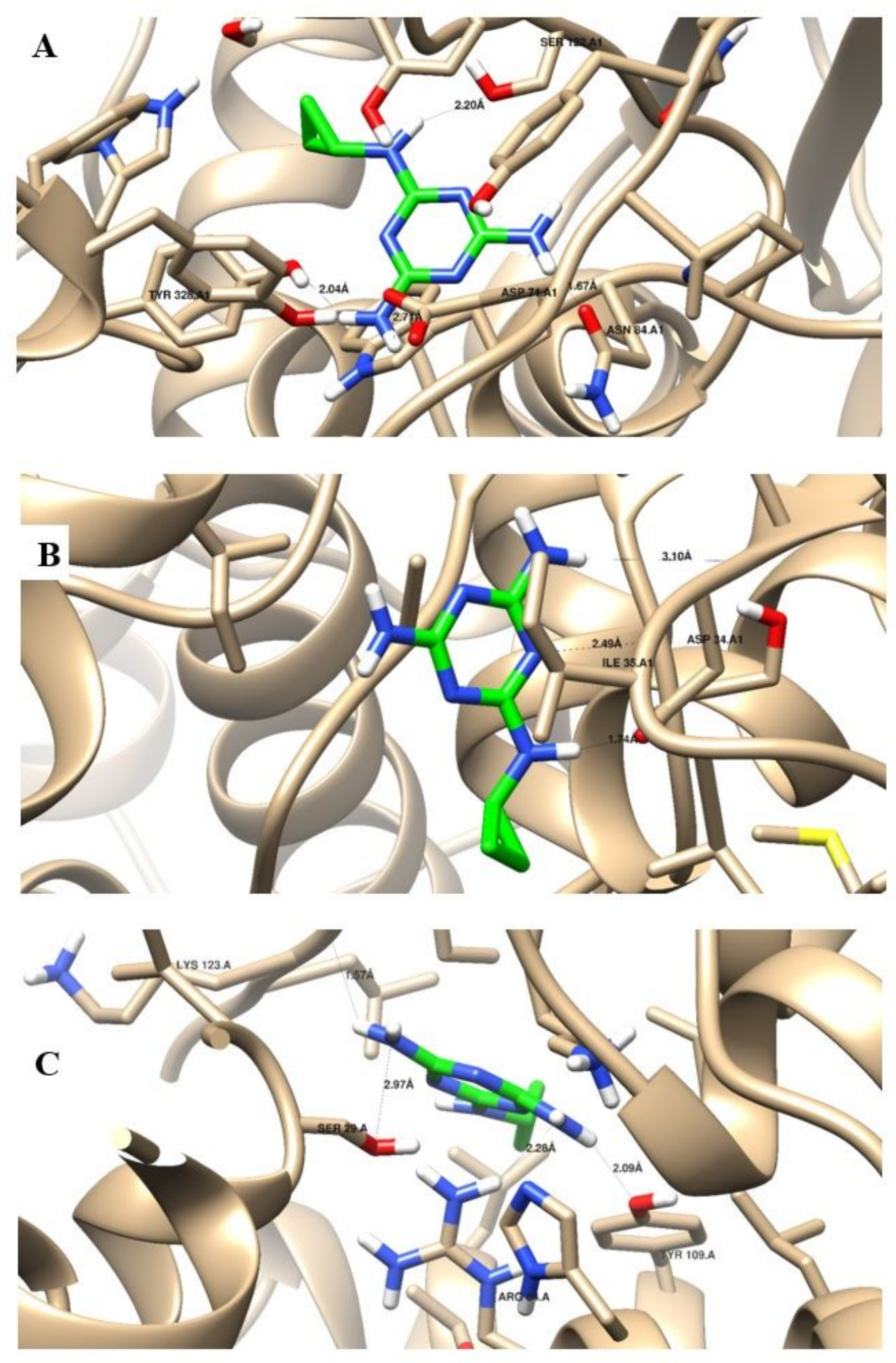

Figure 5

Binding disposition and ligand-receptor interactions of Cyromazine inside A) acetylcholinesterase (AchE),

B) lactate dehydrogenase (LDH), and C) protease (SREBPs).

\section{Supplementary Files}


This is a list of supplementary files associated with this preprint. Click to download.

- SupplementaryMaterialrevised.docx 